\title{
PROFIL PEMAHAMAN MAHASISWA PENDIDIKAN MATEMATIKA FKIP UPP TENTANG KONSEP DASAR PERSAMAAN DIFERENSIAL BIASA
}

\author{
Lusi Eka Afri ${ }^{1}$ \\ Universitas Pasir Pengaraian \\ lusiekaafri13@gmail.com
}

\begin{abstract}
ABSTRAK Persamaan diferensial biasa adalah subjek utama bagi mahasiswa untuk berpikir dalam bentuk implementasi matematika melalui kontekstual untuk memecahkan fenomena dalam masalah kehidupan nyata. Dalam proses belajar persamaan diferensial biasa sulit bagi sebagian mahasiswa. Hal ini disebabkan oleh persamaan diferensial biasa yang melibatkan derivatif, fungsi, dan konsep integral. Penelitian ini adalah penelitian deskriptif. Hal ini bertujuan untuk menggambarkan pemahaman siswa pada konsep dasar persamaan diferensial biasa. Subjek penelitian ini adalah 21 siswa semester $V$ pendidikan matematika Universitas Pasir Pengaraian. Data dikumpulkan melalui tes. Hasil penelitian menunjukkan bahwa penguasaan terhadap pemahaman konsep dasar persamaan diferensial biasa siswa adalah rendah sebesar 51,19\%. Sebagian besar mahasiswa memiliki pemahaman yang rendah dalam hal konsep derivatif dan integral terutama pada fungsi logaritma alami, trigonometri, dan kelalaian faktor akurasi dalam menyelesaikan persamaan diferensial.
\end{abstract}

Kata-Kata Kunci :Pemahaman konsep,Persamaan diferensial biasa

\section{PENDAHULUAN}

Persamaan diferensial biasa merupakan mata kuliah wajib pada program studi pendidikan matematika Fakultas Keguruan dan IImu Pendidikan Universitas Pasir Pengaraian. Mata kuliah ini berkaitan dengan model matematika yang menggambarkan masalah nyata dalam kehidupan sehari-hari. Bagi mahasiswa mata kuliah persamaan diferensial biasa ini dapat mengantarkan kepada pemikiran-pemikiran menerapkan matematika secara konseptual untuk memecahkan masalah gejala alam.

Pada awal mempelajari persamaan diferensial biasa, mahasiswa diharapkan lebih menekankan pada penguasaan konsep dasar matematik dan keterampilan mencari solusi persamaan diferensial. Karena bentuk persamaan diferensial dari suatu gejala alam sangat banyak, maka berbagai teknik untuk mencari solusi persamaan diferensial. Oleh karena itu, mahasiswa perlu memahami konsep persamaan diferensial, membedakan persamaan diferensial biasa dan persamaan diferensial parsial serta memilih teknik dalam mencari penyelesaian persamaan diferensial.

Pada proses pembelajaran persamaan diferensial biasa dianggap sulit bagi mahasiswa. Karena mahasiswa dituntut memiliki kemampuan pemahaman terhadap konsep turunan dan integral. Oleh sebab itu, mata kuliah persamaan 
diferensial biasa diperuntukkan bagi mahasiswa yang sudah mengambil mata kuliah kalkulus. Sejalan dengan pernyataan Valcarce \& Diaz (2013) yang menyebutkan bahwa kesulitan terbanyak mahasiswa dalam belajar persamaan diferensial adalah terletak pada pemahaman konsep persamaan, konsep fungsi dan turunan suatu fungsi.

Pemahaman konsep merupakan kemampuan dalam menguasai materi tertentu. Menurut Kesumawati (2008) pemahaman konsep merupakan kecakapan dalam menjelaskan konsep dan mengaplikasikan konsep atau algoritma secara luwes, akurat, efisien dan tepat dalama pemecahan masalah.

Adapun indikator pemahaman konsep yang dijelaskan oleh Depdiknas (Kesumawati, 2008) antara lain yaitu (1) menyatakan ulang konsep, (2) mengkalsifikasi objek-objek menurut sifat tertentu (sesuai dengan konsepnya), (3) memberikan contoh dan bukan contoh dari konsep, (4) menyajikan konsep dalam berbagai bentuk representative matematis, (5) mengembangkan syarat perlu atau cukup dari suatu konsep, (6) menggunakan, memafaatkan, dan memilih preosedur atau operasi tertentu, dan (7) mengaplikasikan konsep atau algoritma pemecahan masalah.

Berdasarkan informasi yang telah diuraikan, penelitian ini bertujuan untuk mengetahui dan mendeskripsikan profil pemahaman mahasiswa pada konsep dasar persamaan diferensial biasa. Penelitian ini khususnya pada mahasiswa semester $\vee$ yang sudah mengambil mata kuliah kalkulus.

\section{METODE PENELITIAN}

Penelitian ini merupakan penelitian deskriptif. Hal ini berdasarkan pada pendapat Sukardi (2008) menyatakan bahwa penelitian deskriptif merupakan penelitian yang menggambarkan aturan atau menginterpretasikan objek sesuai dengan apa adanya. Penelitian ini bertujuan untuk mendiskripsikan data pemahaman mahasiswa terhadap konsep dasar persamaan diferensial biasa.

Subjek penelitian ini adalah mahasiswa semester $V$ Program Studi Pendidikan Matematika Fakultas Keguruan dan IImu Pendiidkan Universitas Pasir Pengaraian Tahun Ajaran 2018/2019 yang berjumlah 21 orang.

Pengumpulan data menggunakan teknik tes. Instrument tes berupa soal uraian yang mengukur pemahaman mahasiswa terhadap konsep dasar persamaan diferensial biasa. Soal tersebut mencakup indikator kemampuan menyatakan ulang suatu konsep, kemampuan mengklasifikasikan objek-objek menurut sifat-sifat tertentu serta kemampuan menggunakan, memanfaatkan dan memilih prosedur atau operasi tertentu.

\section{HASIL DAN PEMBAHASAN}

Tes tertulis tentang pengusaan mahasiswa terhadap konsep dasar persamaan diferensial biasa diberikan kepada mahasiswa semester $\vee$ kelas yang berjumlah 21 orang. Soal tes yang diberikan berjumlah empat soal yang mencakup pemahaman mahasiswa terhadap konsep persamaan diferensial, klasifikasi 
persamaan diferensial dan penyelesaian persamaan diferensial biasa dengan metode pemisahan variabel dan metode substitusi.

Tabel 1 memperlihatkan penguasaan mahasiswa terhadap konsep dasar persamaan diferensial biasa pada sub materi. Hal ini bertujuan untuk mengetahui pada sub materi apa saja mahasiswa bermalalah.

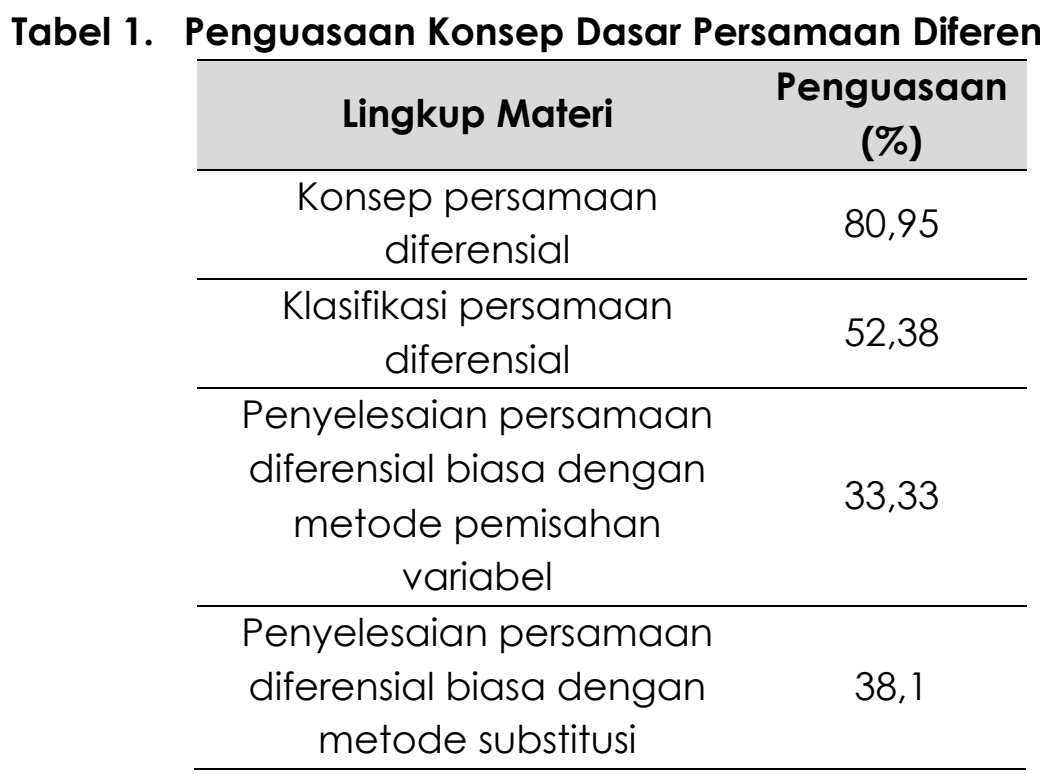

Berdasarkan data pada tabel 1 terlihat bahwa penguasaan tentang konsep dasar persamaan diferensial biasa mahasiswa hanya satu materi yang mencapai lebih dari $75 \%$ yaitu materi tentang definisi dari persamaan diferensial. Sub materi yang berhasil dikuasai oleh mahasiswa lebih dari 50\% yaitu materi tentang pengklasifikasian persamaan diferensial. Sedangkan dua sub materi lainnya kurang dari $50 \%$ yaitu materi penyelesaian persamaan diferensial biasa dengan menggunakan metode pemisahan variabel dan metode substitusi.

Pemahaman mahasiswa dalam menyatakan kembali definisi dari persamaan diferensial sudah baik. Hanya $19.05 \%$ mahasiswa yang belum memahami tentang definisi persamaan diferensial. Kelemahan mahasiswa terlihat dari jawaban pertanyaan yang diajukan kepada mahasiswa. Indikator yang tidak dikuasai mahasiswa dengan benar yaitu tidak memahami dalam suatu fungsi mana yang merupakan variabel bebas (independen) dan mana yang merupakan variabel tak bebas (dependen) serta prinsip diferensial. Gambar 1 menyajikan salah satu jawaban mahasiswa yang salah. Sedangkan jawaban yang benar dapat dilihat pada Gambar 2. Pada Gambar 2 terlihat bahwa mahasiswa dalam menyatakan definisi persamaan diferensial dengan benar.

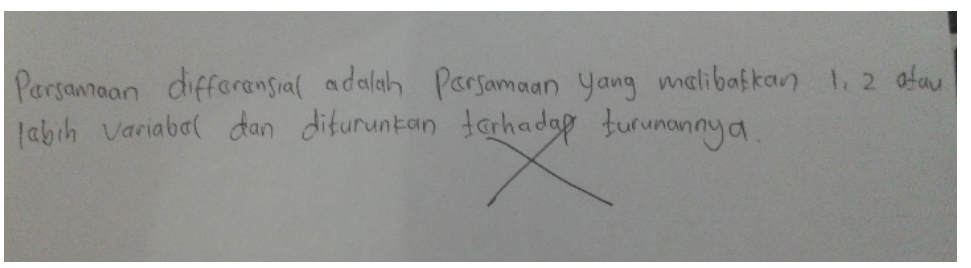

Gambar 1. Jawaban mahasiswa soal nomor 1 yang salah 


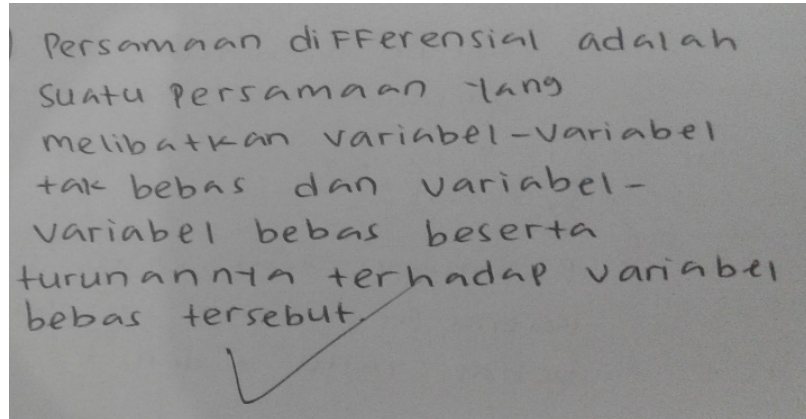

\section{Gambar 2. Jawaban mahasiswa soal nomor 1 yang benar}

Pemahaman mahasiswa dalam mengklasifikasikan persamaan diferensial mencapai lebih dari 50\%. Mahasiswa mampu mengklasifikasikan persamaan diferensial berdasarkan banyak variabel bebas pada persamaan tersebut. Dimana persamaan diferensial yang terdiri dari satu variabel bebas (independen) disebut dengan persamaan diferensial biasa, sedangkan persamaan diferensial yang terdiri dari lebih satu variabel bebas disebut dengan persamaan diferensial parsial. Gambar 3 disajikan salah satu jawaban mahasiswa yang benar mengenai pengklasifikasian persamaan diferensial. Hal ini menunjukkan bahwa mahasiswa memiliki kemampuan mengklasifikasi objek berdasarkan sifatnya (sesuai dengan konsepnya).

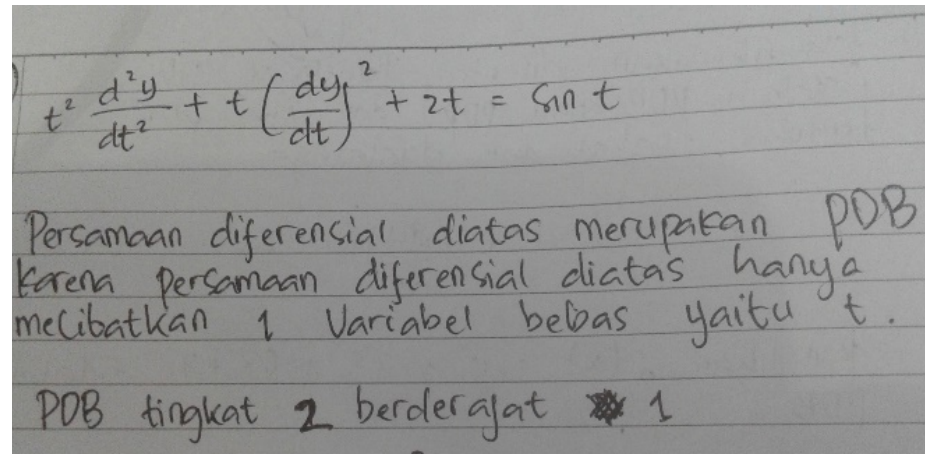

\section{Gambar 3. Jawaban mahasiswa soal nomor 2 yang benar}

Akan tetapi, hampir 50\% mahasiswa juga belum bisa dalam pengklasifikasian persamaan diferensial sesuai dengan konsepnya. Kelemahan mahasiswa terlihat pada indikator penentuan variabel bebas atau variabel terikat. Mahasiswa belum memiliki pemahaman dalam menentukan variabel bebas dan variabel terikat pada suatu persamaan diferensial. Gambar 4 disajikan jawaban mahasiswa yang salah dimana mahasiswa dalam mengklasifikasikan persamaan diferensial tidak tepat karena tidak sesuai dengan konsepnya. Hal ini menunjukkan bahwa mahasiswa memiliki kemampuan mengklasifikasi objek berdasarkan sifatnya (sesuai dengan konsepnya) 


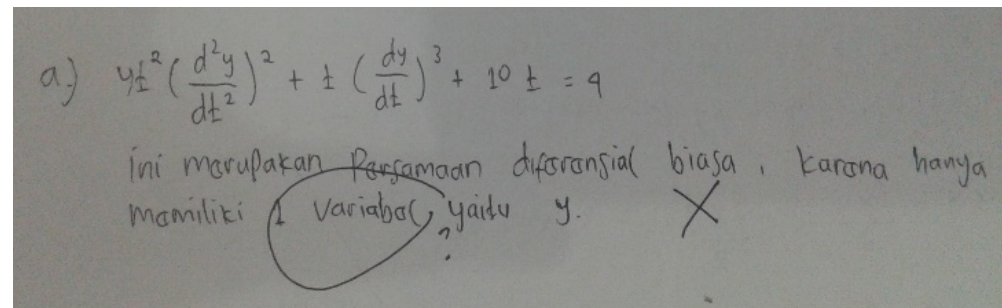

\section{Gambar 4. Jawaban mahasiswa soal nomor 2 yang salah}

Kemampuan mahasiswa dalam menyelesaikan persamaan diferensial biasa sangat rendah. Pada soal ketiga diberikan soal berupa persamaan diferensial biasa orde satu tingkat satu dengan prosedur penyelsaiannya menggunakan metode pemisahan variabel dan dengan menggunakan teknik pengintegralan akan diperoleh solusi persamaan. Pada gambar 5 terlihat bahwa mahasiswa belum mengetahui bentuk umum persamaan diferensial dan belum mampu dalam memisahkan variabel. Dalam hal ini mahasiswa dituntut memahami bentuk umum persamaan diferensial dan mengetahui metode yang tepat untuk mencari penyelesaian persamaan diferensial tersebut.

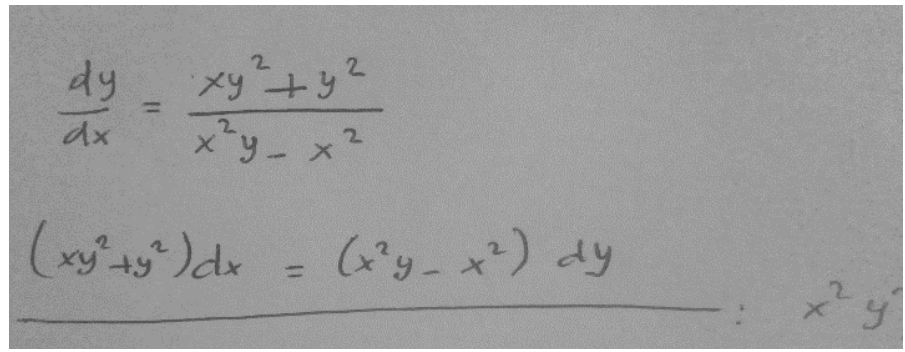

\section{Gambar 5. Jawaban mahasiswa soal nomor 3 yang salah}

Pada gambar 6 terlihat bahwa mahasiswa dapat melihat persamaan diferensial merupakan persamaan diferensial biasa orde satu dimana dua variabel masih terletak pada suku yang sama. Dalam hal ini mahasiswa dapat memperkirakan bahwa variabel yang berdampingan dalam satu suku dapat dipisah sehingga dalam satu suku hanya terdiri dari satu variabel. Dengan kata lain mahasiswa mulai mampu dalam menggunakan, memanfaatkan dan memilih operasi tertentu. Akan tetapi, kelemahan mahasiswa terlihat pada teknik pengintegralan untuk langkah selanjutnya. Kesalahan mahasiswa terletak pada kurang pahamnya mahasiswa pada konsep integral terutama dalam mengintegralkan fungsi logaritma natural. Bahkan juga kesalahan terlihat operasi perkalian negatif dan positif. 


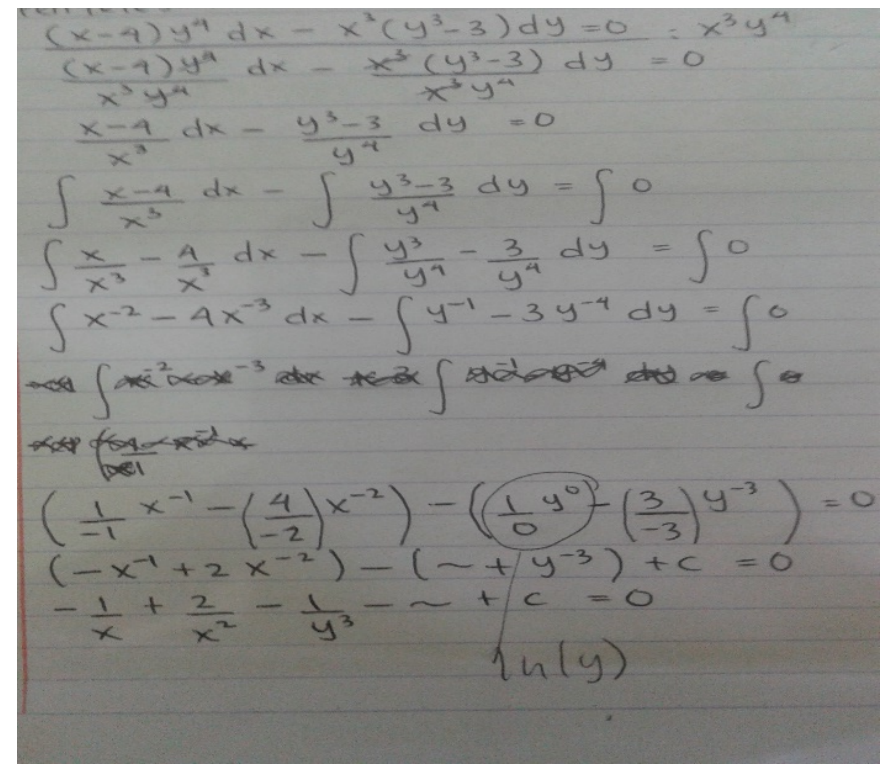

Gambar 6. Jawaban mahasiswa soal nomor 3 yang salah

Selain itu, pemahaman mahasiswa dalam memilih prosedur terlihat dalam menyelsaikan soal keempat. Soal keempat diberikan persamaan diferensial homogen untuk dicarikan penyelesaiannya. Prosedurnya menentukan penyelesaian persamaan diferensial homogen adalah mahasiswa terlebih dahulu mengidentifikasi apakah persamaan diferensial tersebut merupakan persamaan diferensial homogen atau tidak. Selanjutnya metode substitusi dapat digunakan untuk penyelesaian persamaan diferensial tersebut. Sebagian besar mahasiswa tidak menunjukkan bahwa persamaan diferensial homogen. Pada gambar 7 terlihat mahasiswa memaksakan untuk melakukan pemisahan variabel dimana dalam satu suku masih memiliki variabel berbeda.

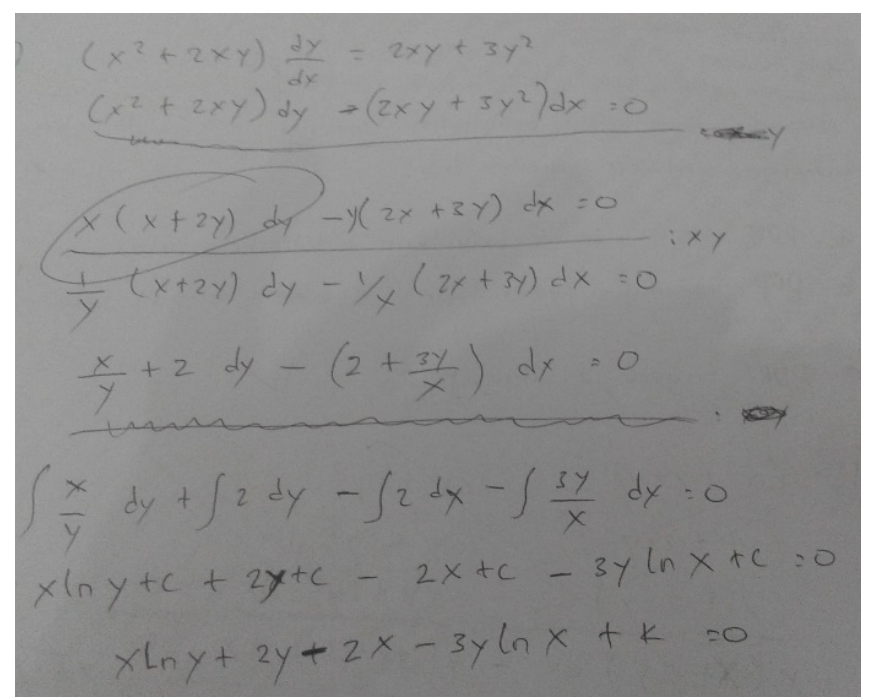

Gambar 7. Jawaban mahasiswa soal nomor 4 yang salah 


\section{KESIMPULAN DAN SARAN}

Kesimpulan yang diperoleh dari hasil penelitian ini adalah sebagai berikut :

1. Rata-rata penguasaan konsep dasar persamaan diferensial biasa mahasiswa pendidikan matematika semester $\vee$ yaitu $51.19 \%$.

2. Materi yang tingkat penguasaannya dibawah $50 \%$ adalah penyelesaian persamaan diferensial biasa baik metode pemisahan variabel maupun metode substitusi.

Berdasarkan hasil tersebut, dapat disimpulkan bahwa penguasaan konsep dasar persamaan diferensial biasa mahasiswa pendidikan matematika semester $\vee$ masih rendah. Oleh karena itu, melihat hasil kajian yang didapatkan, maka diajukan saran yaitu

1. Kesulitan mahasiswa dalam menyelesaikan persamaan diferensial terjadi karena rendahnya penguasaan konsep dasar integral. Pembelajaran tentang topik turunan dan integral terpaku pada menghafal rumus terutama pada fungsi logaritma natural dan trigonometri. Konsep integral harus dikuasai mahasiswa karena mata kuliah kalkulus merupakan mata kuliah prasyarat.

2. Kurangnya ketelitian mahasiswa dalam menyelesaikan soal persamaan diferensial. Faktor ketelitian sering diabaikan.

\section{DAFTAR PUSTAKA}

Didit Budi Nugroho. 201 1. Persamaan Diferensial Biasa dan aplikasinya.Yogyakarta: PT Graha llmu

Katikasari, M \& Khotimah, R.P. 2015. Pola Pikir Mahasiswa dalam Menyelesaikan Persamaan Differensial Ditinjau dari Gaya Kognitif Filed Dependent dan Gaya Belajar Reflectors. Prosiding Seminar Nasional Pendidikan Matematika Ums 2015. ISBN : 978.602.719.934.7

Kesumawati. 2008. Pemahaman Konsep Matematik dalam Pembelajaran Matematika. Tersedia: http://eprints.uny.ac.id/6928/1/P18\%20Pendidikan\%28Nila\%20K\%29.pdf.

Ningsih, Y.L \& Rohana. 2018. Pemahaman Mahasiswa terhadap Persamaan Diferensial Biasa berdasarkan Teori APOS. Jurnal Penelitian dan Pembelajaran Matematika, Volume 11(1), hal 168-176.

Ross Shapley L. 1989. Introduction to Ordinary Diferensial Equations. Singapore : John Wiley \& Sons

Santoso, W \& Pamunjtjak R.J. 1999. Persamaan Diferensial Biasa. Jakarta : Diejen DIKTI 
Syafiah, L.L. 2017. Analisis Kemampuan Pemahaman Matematis pada Mata Kuliah Pembelajaran Matematika SMA II. Jurnal Penelitian dan Pembelajaran Matematika, Volume 10 (2). Hal58-71.

Valcare, M C, \& Diaz, J. P. 2013. Initial Diagnostic Assessment to Support Learning. Tersedia :http://cerme8.metu.edu.tr/wgpapers/WG14 Codes Valcarce.pdf. 